\title{
Inheritance of Resistance to Watermelon mosaic virus in Cucumis melo that Impairs Virus Accumulation, Symptom Expression, and Aphid Transmission
}

\author{
Juan Antonio Díaz-Pendón, Rafael Fernández-Muñoz, María Luisa Gómez-Guillamón, and Enrique Moriones
}

Estación Experimental "La Mayora", Consejo Superior de Investigaciones Científicas (CSIC), 29750 Algarrobo-Costa, Málaga, Spain. Accepted for publication 14 March 2005.

\begin{abstract}
Díaz-Pendón, J. A., Fernández-Muñoz, R., Gómez-Guillamón, M. L., and Moriones, E. 2005. Inheritance of resistance to Watermelon mosaic virus in Cucumis melo that impairs virus accumulation, symptom expression, and aphid transmission. Phytopathology 95:840-846.

The Cucumis melo accession TGR-1551 was found to be resistant to Watermelon mosaic virus (WMV, genus Potyvirus, family Potyviridae).

tion and ameliorated symptom expression. No effect was observed on virus accumulation in inoculated leaves, which suggested that the initial phases of infection were not affected. The resistance was effective against a range of WMV isolates from Spanish melon production areas. Using aphid inoculations, resistant plants showed a lower propensity for infection by WMV and for serving as virus sources for secondary spread once infected. Resistance was determined to be under recessive genetic control.
\end{abstract} The resistance resulted in a drastic and significant reduction of virus titer and infected plants were asymptomatic or exhibited mild disease symptoms. The same gene or closely linked genes restricted virus accumula-
Additional keywords: potyvirus resistance, recessive resistance.
Most melon (Cucumis melo L.) cultivars are susceptible to a number of mosaic diseases caused by aphid-borne viruses. These viruses are a worldwide problem for field-grown melons and include the cucumovirus (genus Cucumovirus, family Bromoviridae) Cucumber mosaic virus (CMV) and the potyviruses (genus Potyvirus, family Potyviridae) Papaya ringspot virus strain W (PRSV$\mathrm{W}$ ), Watermelon mosaic virus (WMV), and Zucchini yellow mosaic virus (ZYMV) $(2,12,24,32,38,45)$. Although the relative importance of mosaic-inducing viruses in field-grown melons varies between regions and years, CMV and WMV are common in many production areas such as California $(24,45)$, Hawaii $(63)$, Italy (35), Spain (2,38), and Turkey (58).

Mosaic-inducing viruses are of great concern for melon growers because, in addition to mosaic symptoms, serious yield and quality loss may occur $(1,7)$. Transmission in nature occurs in a nonpersistent manner by different aphid (Hemiptera, Aphididae) species, with Aphis gossypii Glover and Myzus persicae Sulz. being efficient vectors in the field $(10,13)$. Aphids can acquire and inoculate these viruses during superficial probes that take only a few seconds (33), making prevention of spread through the use of insecticides impractical $(49,53)$.

Mosaic-inducing viruses seriously limit melon production, and much effort has been directed toward identifying sources of resistance. Commercial melons with resistance to CMV and PRSV-W have been produced (32), but melon cultivars with resistance to WMV or ZYMV are not available even though resistance to these viruses has been reported $(3,14,22,25)$. We recently screened a collection of $C$. melo and wild species accessions for useful sources of resistance to mosaic-inducing viruses and found that the $C$. melo accession TGR-1551 exhibited resistance to WMV (16). This study describes the phenotype and inheritance of WMV resistance derived from TGR-1551.

Corresponding author: E. Moriones; E-mail address: moriones@eelm.csic.es

DOI: 10.1094/PHYTO-95-0840

(c) 2005 The American Phytopathological Society

\section{MATERIALS AND METHODS}

Plant materials, virus isolates, and aphid colonies. Seed of the parental genotypes used in this study were obtained from the CSIC-La Mayora germ plasm bank. The melon accession TGR1551, originally collected in Zimbabwe and maintained by selfpollination, previously was suggested as a possible source of WMV resistance (16). C. melo 'Bola de Oro' and PMR 45 were used as susceptible controls. Inheritance of WMV resistance in TGR-1551 was studied using the two parents (TGR-1551 and 'Bola de Oro'), their $\mathrm{F}_{1}$ hybrid and $\mathrm{F}_{2}$ generations, a first backcross to the resistant parent $\left(\mathrm{F}_{1} \times \mathrm{TGR}-1551, \mathrm{BC}_{1 \mathrm{R}}\right)$, and a first backcross to the susceptible parent $\left(\mathrm{F}_{1} \times\right.$ 'Bola de Oro', $\left.\mathrm{BC}_{1 \mathrm{~S}}\right)$.

Twenty-one isolates of WMV (Table 1) were used to evaluate resistance of TGR-1551. 'Bola de Oro' also was inoculated with each isolate as a control. Four plants were tested for each virus isolate-plant genotype combination. The WMV isolates were selected randomly from a collection obtained during a survey of major areas of melon field production in Spain. Prior to inoculation, pure stocks of each virus isolate, not containing other viruses or other WMV isolates, were obtained by single-local-lesion transfers as described previously (42). CMV isolate M730 and ZYMV isolate C16 were described by Díaz et al. (16). Infectious virus stocks were maintained at $4^{\circ} \mathrm{C}$ as lyophilized infected leaves.

Nonviruliferous $M$. persicae individuals were obtained from colonies reared on pepper (Capsicum annuum L.) 'California Wonder' $F_{1}$ (Ramiro Arnedo S.A., La Rioja, Spain) plants. Nonviruliferous $A$. gossypii individuals were obtained from colonies reared on melon (accession ANC-42, CSIC-La Mayora germ plasm bank) plants.

Inoculation and symptom evaluation. Mechanical and aphid inoculations were performed as described previously (61). Mechanical inoculations were performed on cotyledons of plants at expanded cotyledons and emerging-first-leaf growth stage. Aphid inoculations were performed onto the first leaf of plants at expanded-cotyledons and one-leaf growth stages. For transmission studies, two levels of infestation were examined, 4 aphids (six 
experiments) or 10 aphids (four experiments) per plant. In every replicate, transmission to 15 healthy plants of each TGR-1551 and 'Bola de Oro' genotypes was performed. TGR-1551 was not inoculated using A. gossypii because previous studies (61) have indicated that it is resistant to virus transmission by this aphid species. Virus sources for mechanical inoculations were young leaves of infected zucchini squash ('Diamante' $\mathrm{F}_{1}$; Seminis Vegetable Seeds Iberica, Almería, Spain) harvested 15 days postinoculation. Except when indicated, virus sources for aphid inoculations were young leaves of infected PMR 45 melon plants. Mockinoculated (mechanically with inoculation buffer or by using virus-free aphids) plants served as negative controls. Experiments were conducted in an insect-proof glasshouse at $\approx 25$ and $18^{\circ} \mathrm{C}$ (day and night, respectively) and a day length of $16 \mathrm{~h}$, with light supplementation when needed (inoculation of the collection of WMV isolates); or in a growth-chamber at 25 and $22^{\circ} \mathrm{C}$ (day and night, respectively), $70 \%$ relative humidity, and a 16 -h photoperiod (radiation level at 400 to $700 \mathrm{~nm}, 120 \mu \mathrm{mol} \mathrm{m} \mathrm{m}^{-2} \mathrm{~s}^{-1}$ ) (aphid inoculation and genetic analysis). Inoculated plants were assessed up to 6 weeks postinoculation (wpi) (6- to 10-leaf growth stage). Symptoms were rated according to an integer scale of 0 to 5 , where $0=$ no symptoms; $1=$ apical leaf with dispersed vein clearing or mottle, and no mosaic; $2=$ mild mosaic only in the apical leaf; $3=$ mild mosaic and mild leaf distortion in the three youngest leaves; $4=$ mosaic and leaf distortion in the three or four youngest leaves; and $5=$ severe mosaic and leaf distortion in the five or six youngest leaves. For the examination of resistance in $\mathrm{F}_{2}$ and $\mathrm{BC}_{1 \mathrm{R}}$ populations, plants with a symptom score $\leq 2$ were considered resistant. Curves of symptom progress were constructed, and the area under the symptom progress curve (AUSPC) was determined using the following formula: AUSPC $=\Sigma_{i}\left(\left[x_{i}+\right.\right.$ $\left.\left.x_{1+i}\right] / 2\right) t_{i}$, where $x_{i}=$ mean value of disease score at date $i$, and $t_{i}=$ time (in days) between scoring date $i$ and scoring date $i+1$ (8). The AUSPC formula integrates disease severity between several assessment times using the trapezoidal integration method, dividing the symptom progress curve into a series of rectangles and summing the area of each rectangle to approximate the total area under the curve (8). AUSPC can be used as a descriptor of the disease progression (9).
Virus detection and quantification. Double-antibody sandwich enzyme-linked immunosorbent assay (DAS-ELISA) (11) was used to detect the presence of virus in plants as described previously (16), using commercial polyclonal antisera for WMV, CMV, or ZYMV (Loewe Biochemica GmbH, Otterfing, Germany). When needed, the amount of WMV present in inoculated plants was determined based on DAS-ELISA from extracts obtained as described previously (16). To avoid sampling bias due to nonuniform virus distribution in plant tissues, whole cotyledons or leaves were analyzed. For quantitative DAS-ELISA, a preparation of M116-WMV virus particles was obtained as described previously (42). Known amounts $(25,50,100,150$, and $250 \mathrm{ng})$ of M116-WMV preparation were included as controls in each ELISA plate to obtain the standard curve that related absorbance at $405 \mathrm{~nm}$ value to virus concentration. Serial dilutions (wt/vol) of sample extracts included 1:10, 1:100, and 1:500 for cotyledons and young leaves of TGR-1551 or of asymptomatic plants of any genotype; and dilutions of 1:500, 1:1,000, 1:5,000, 1:10,000, and $1: 20,000$ for young leaves of symptomatic plants. Three replicate wells were included for each sample, from which mean absorbance value was calculated. Absorbance values used for quantification in every ELISA plate were only those from dilutions that placed within the linear range of the relationship between sample dilution and absorbance values.

Distribution of WMV in entire leaves of infected plants was studied by immunoblot analysis after leaf-press blotting. Leaves were frozen at $-80^{\circ} \mathrm{C}$ and then blotted onto a nitrocellulose membrane as described previously (62). The detection procedure, based on the method described by Hawkes et al. (29), included blocking the membranes with $4 \%$ no-fat milk powder in $1 \times$ AFT $(136 \mathrm{mM}$ $\mathrm{NaCl}, 250 \mathrm{mM} \mathrm{NaH} \mathrm{PO}_{4} \cdot 2 \mathrm{H}_{2} \mathrm{O}, 8 \mathrm{mM} \mathrm{Na} 2 \mathrm{HPO}_{4} \cdot 12 \mathrm{H}_{2} \mathrm{O}, \mathrm{pH}$ 7.2 to 7.4 ) containing $0.5 \%$ ( $\mathrm{vol} / \mathrm{vol}$ ) Tween 20 . Virus was localized by using WMV alkaline phosphatase (AP)-conjugated immunoglobulin Gs (Loewe Biochemica $\mathrm{GmbH}$ ). The membrane was developed by incubating with luminescent substrate (CDPStar, Roche Diagnostics GmbH, Mannheim, Germany), and exposed to X-ray films (Kodak, X-Omat AR).

Statistical and inheritance analyses. Statistical analyses were performed using the statistical software SPSS for Windows

TABLE 1. Geographic origin, year of collection, and host species from which the Watermelon mosaic virus (WMV) isolates used in this study originally were collected

\begin{tabular}{|c|c|c|c|}
\hline Geographic origin & WMV isolate ${ }^{\mathrm{z}}$ & Host species & Year of collection \\
\hline \multicolumn{4}{|l|}{ Western Spain } \\
\hline \multirow[t]{2}{*}{ Badajoz } & M95/14 (BAD95.1) & Cucumis melo & 1995 \\
\hline & M95/47 (BAD95.3) & C. melo & 1995 \\
\hline \multirow[t]{4}{*}{ Barcelona } & B9.2 (BAR95.1) & C. melo & 1995 \\
\hline & B10.1 (BAR95.2) & C. melo & 1995 \\
\hline & M719 (BAR99.3) & C. melo & 1999 \\
\hline & M721 (BAR99.5) & C. melo & 1999 \\
\hline Zaragoza & M780 & C. melo & 1999 \\
\hline \multicolumn{4}{|l|}{ Central Spain } \\
\hline \multirow[t]{5}{*}{ Madrid } & M95/158.8 (MAD95.1) & C. melo & 1995 \\
\hline & M95/162.8 (MAD95.4) & C. melo & 1995 \\
\hline & M95/303.8 (MAD95.8) & C. melo & 1995 \\
\hline & M95/323.8 (MAD95.7) & C. melo & 1995 \\
\hline & M730W277 (MAD99.2) & C. melo & 1999 \\
\hline \multirow[t]{3}{*}{ Murcia } & M239 & C. melo & 1995 \\
\hline & M236 (MUR95.2) & C. melo & 1995 \\
\hline & M261 (MUR95.4) & C. melo & 1995 \\
\hline Valencia & M116 (VAL95.1) & C. melo & 1995 \\
\hline
\end{tabular}

${ }^{\mathrm{z}}$ The code name used in Moreno et al. (42) is shown in parentheses. 
(release 11.0.1; SPSS Inc., Chicago). To stabilize variance and normalize data distributions, values for virus quantities were $\log _{10}$ transformed and percentages of aphid transmission were arcsinetransformed prior to analysis. Correlations between AUSPCs, symptom scores, and virus accumulation data were calculated using Pearson's $r$ product-moment coefficient. Separations of means were made using the Games-Howell test $(P \leq 0.05)$, an analysis of variance-based post hoc procedure suitable for cases in which treatment variances are nonhomogeneous. Determination of the number of loci involved in the inheritance of resistance in the TGR-1551 $\times$ 'Bola de Oro' genetic family were made upon $\chi^{2}$ testing of departure from expected resistant:susceptible ratios for different genetic models.

\section{RESULTS}

Effective resistance of TGR-1551 to Spanish isolates of WMV. An initial screening of TGR-1551 resistance was performed by mechanical inoculation of this breeding line with 21 isolates representative of the Spanish WMV population (Table 1), including WMV isolate M116 used for preliminary screening (16). All plants of TGR-1551 exhibited uniform resistance to all 21 isolates of WMV tested. No appreciable difference was observed between virus-inoculated TGR-1551 and mock-inoculated TGR-1551 plants even at $6 \mathrm{wpi}$, except for a few plants for which scattered chlorotic mottle, vein clearing, or mosaic was barely visible in young leaves at that time (Fig. 1B). In contrast, all inoculated 'Bola de Oro' plants exhibited severe symptoms (severe mosaic, leaf distortion, and stunting) with all $21 \mathrm{WMV}$ isolates after 1 wpi (Fig. 1D). DAS-ELISA analysis of young, noninoculated leaves at 5 wpi indicated that WMV was present in all the 'Bola de Oro' and TGR-1551 plants inoculated except for isolates S748 and M95/47, which were not detected in any of the TGR1551 plants tested. WMV was not detected nor were symptoms observed in mock-inoculated plants (Fig. 1A and C). No appreciable differences were observed in symptoms or virus titer between

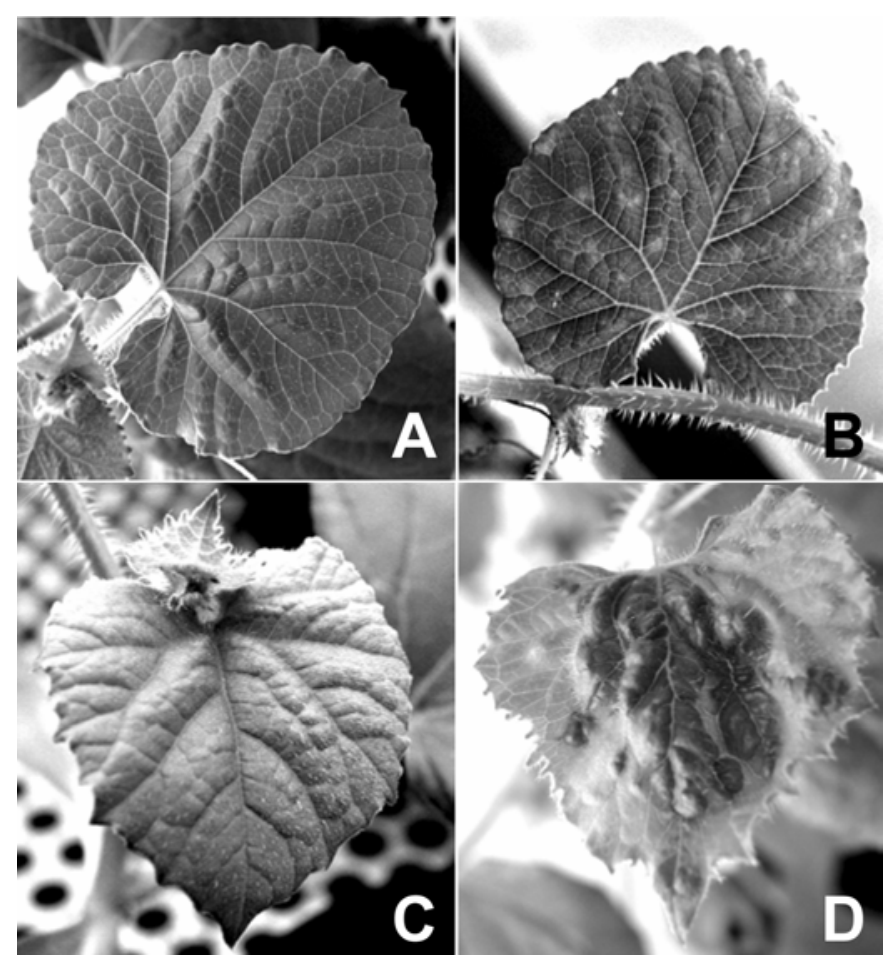

Fig. 1. Systemic symptoms observed in plants of B, TGR-1551 or D, 'Bola de Oro' 6 weeks after mechanical inoculation with Watermelon mosaic virus isolate M-116 compared with A and C, mock-inoculated plants of each genotype, respectively. In TGR-1551 plants, no symptoms were observed in most of the inoculated plants; a few exhibited the mild symptoms shown in $\mathbf{B}$. the WMV isolates that infected TGR-1551. Therefore, more detailed analysis were performed using M116-WMV as a representative isolate.

WMV accumulation and symptom expression are impaired in TGR-1551. The amount of virus present in TGR-1551 and 'Bola de Oro' plants was studied after mechanical inoculation with M116-WMV. The inoculated cotyledons were analyzed at 1 wpi, and the youngest, newly developed leaf was analyzed at 1 , 2, 3, and 4 wpi. Because a destructive sampling method was used, only one cotyledon per plant was analyzed for all plants, and quantification in young leaves was from groups of five plants per sampling date that then were discarded. Symptoms were evaluated twice per week. No symptoms were observed in the cotyledons at any time for either TGR-1551 or 'Bola de Oro' plants. DAS-ELISA analysis indicated that WMV was present in all the inoculated cotyledons, and that a significantly greater (GamesHowell test, $P \leq 0.05$ ) mean amount of virus was present in TGR1551 than in 'Bola de Oro' plants (Fig. 2, open and black boxes, respectively). The initial infection phases, therefore, were not impaired in TGR-1551. In contrast, significantly greater levels of virus were detected consistently through 6 wpi in young noninoculated leaves of 'Bola de Oro' compared with TGR-1551. Virus was not detected in young leaves of TGR-1551 plants until 3 wpi, and subsequent virus titers were always $<1 \%$ of those detected in 'Bola de Oro' plants (Fig. 2, dashed and spotted boxes, respectively). The greatest virus titers in TGR-1551 plants were detected at 4 wpi. Systemic accumulation of WMV obviously was impaired in TGR-1551 relative to accumulation in 'Bola de Oro'. Moreover, symptom development differed significantly between plants of the two genotypes. 'Bola de Oro' plants exhibited severe symptoms 1 wpi, with the highest symptom scores obtained 3 wpi. In contrast, symptoms were not observed in any of the TGR-1551 plants until 4 wpi, with only very mild mosaic or scattered vein clearing symptoms observed in a few plants, always with a rating $<2$ (Fig. 2, open circles curve). Infection was visually evident only in those plants in which symptoms rated $\geq 3$. Differences in symptom development between TGR-1551 and 'Bola de Oro' plants (Fig. 2) resulted in large differences in disease severity suffered by each genotype during the evaluation period as estimated by AUSPCs (AUSPC TGR-1551 $_{\text {A }}=6$; AUSPC $_{\text {'Bola de Oro }}=127$ ). A similar result also was obtained after aphid inoculation using M116-WMV and $M$. persicae (20 aphids per plant). A. gosypii was not used as vector because resistance to virus inoculation by this vector is present in TGR-1551 (16,59). In the case of aphid inoculation, differences with 'Bola de Oro' were even more pronounced because no symptoms at all were exhibited by any of the inoculated TGR-1551 plants although, as before, low amounts of virus could be detected in young, noninoculated leaves (data not shown).

Limited distribution of WMV in TGR-1551-infected leaves. The location and distribution of WMV in young, noninoculated leaves of TGR-1551 or 'Bola de Oro' plants systemically infected with M116-WMV, by mechanical or aphid inoculation, was examined 3 wpi by leaf-press blotting assays. Clear differences were observed between TGR-1551 and 'Bola de Oro' plants. WMV was present in a limited number of infection foci with reduced size in leaves of TGR-1551 plants whereas, in 'Bola de Oro', the virus was distributed uniformly throughout the leaf (Fig. 3). This result was consistent with the lower amount of virus detected in equivalent leaves after DAS-ELISA analysis of TGR-1551 or 'Bola de Oro' plants (Fig. 2).

Resistance to aphid transmission of WMV in TGR-1551. The possible epidemiological consequences derived from the use of a resistant genotype like TGR-1551, which supports low virus titers, was studied in experiments using $M$. persicae and A. gossypii as vectors and either 'Bola de Oro' or TGR-1551 as virus sources. Results showed that TGR-1551 had a significantly lower rate of infection using virus acquired from 'Bola de Oro' 
(4 and 10 aphids per plant) (Table 2). Previous work indicated that TGR-1551 has a resistance mechanism that prevents A. gossypii from initiating ingestion from the phloem, but superficial probes are performed, aphid stylets reach the phloem, and salivation occurs (21). Therefore, acquisition and transmission of a nonpersistent virus like WMV was expected for A. gossypii from TGR1551 plants. In fact, our results showed that both $A$. gossypii and $M$. persicae were able to acquire and transmit WMV from TGR1551 , with no significant difference in rates of infection of TGR1551 and 'Bola de Oro' (Table 2). However, compared with 'Bola de Oro', TGR-1551 was a significantly less efficient virus source with either aphid species at both levels of infestation (Table 2).

Recessive inheritance of resistance to WMV in TGR-1551. The mode of inheritance of the resistance to WMV found in TGR1551 was determined using mechanical inoculation with M116WMV. Symptom expression was monitored for 5 wpi, AUSPC was calculated, and the amount of virus in the youngest noninoculated leaf 4 wpi was analyzed in a number of plants of TGR-1551, 'Bola de Oro', $\mathrm{F}_{1}$ (7 plants of each genotype), and $\mathrm{F}_{2}, \mathrm{BC}_{1 \mathrm{R}}$, and $\mathrm{BC}_{1 \mathrm{~S}}$ plants $(61,27$, and 33 plants, respectively). TGR-1551 and 'Bola de Oro' plants behaved as described above. The $F_{1}$ and $\mathrm{BC}_{1 \mathrm{~S}}$ plants showed the phenotype of the susceptible parent. Plants of the $\mathrm{F}_{2}$ and the $\mathrm{BC}_{1 \mathrm{R}}$ populations exhibited segregation for the three variables described above. In these segregating populations, significant positive correlations were obtained between AUSPCs and symptom scores 5 wpi $(r=0.681, P \leq 0.001$ for the $\mathrm{F}_{2} ; r=0.831, P \leq 0.001$ for the $\left.\mathrm{BC}_{1 \mathrm{R}}\right)$. Also, the amount of virus detected in young leaves positively correlated with symptom scores $\left(r=0.665, P \leq 0.001\right.$ for the $\mathrm{F}_{2} ; r=0.826, P \leq 0.001$ for the $\left.\mathrm{BC}_{1 \mathrm{R}}\right)$ and AUSPCs $\left(r=0.842, P \leq 0.001\right.$ for the $\mathrm{F}_{2} ; r=0.846$, $P \leq 0.001$ for the $\left.\mathrm{BC}_{1 \mathrm{R}}\right)$. All 'Bola de Oro' plants were susceptible, whereas all TGR-1551 plants were resistant (Table 3). All $\mathrm{F}_{1}$

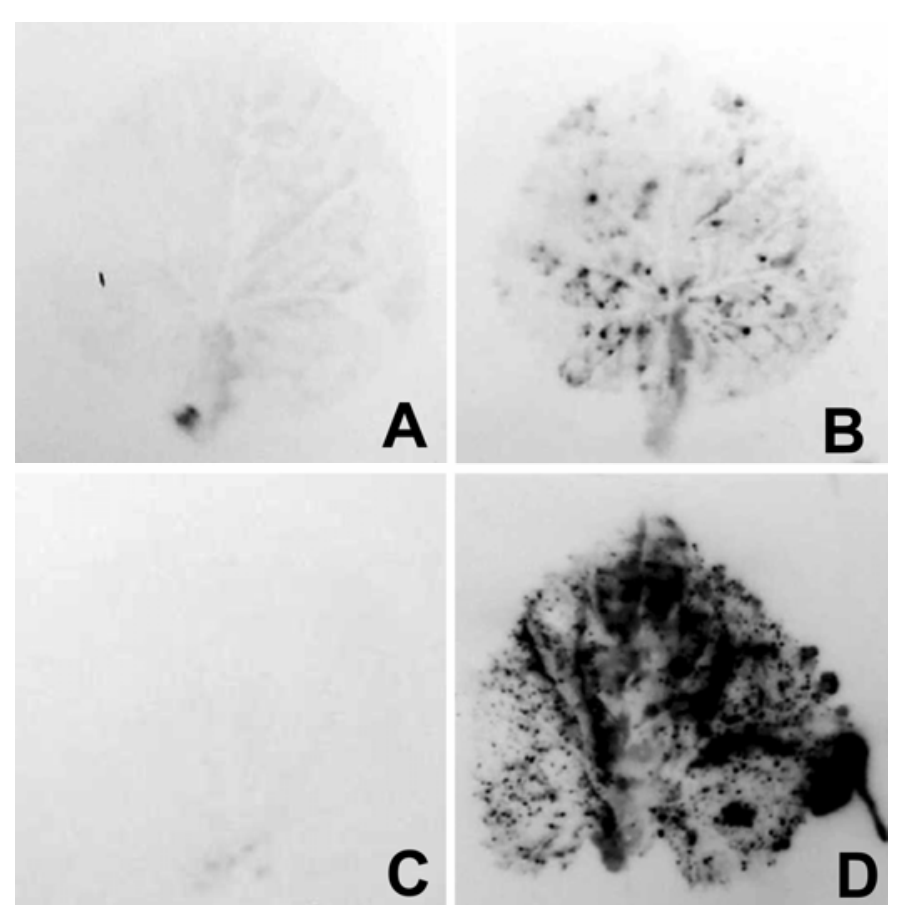

Fig. 3. Watermelon mosaic virus (WMV) location and distribution in entire young noninoculated leaves of B, TGR-1551 and D, 'Bola de Oro' plants inoculated mechanically with WMV isolate M-116 or A and C, mock-inoculated, respectively 3 weeks earlier at expanded cotyledons growth stage. Leaf-press blots were obtained and analyzed using an anti-WMV antibody.

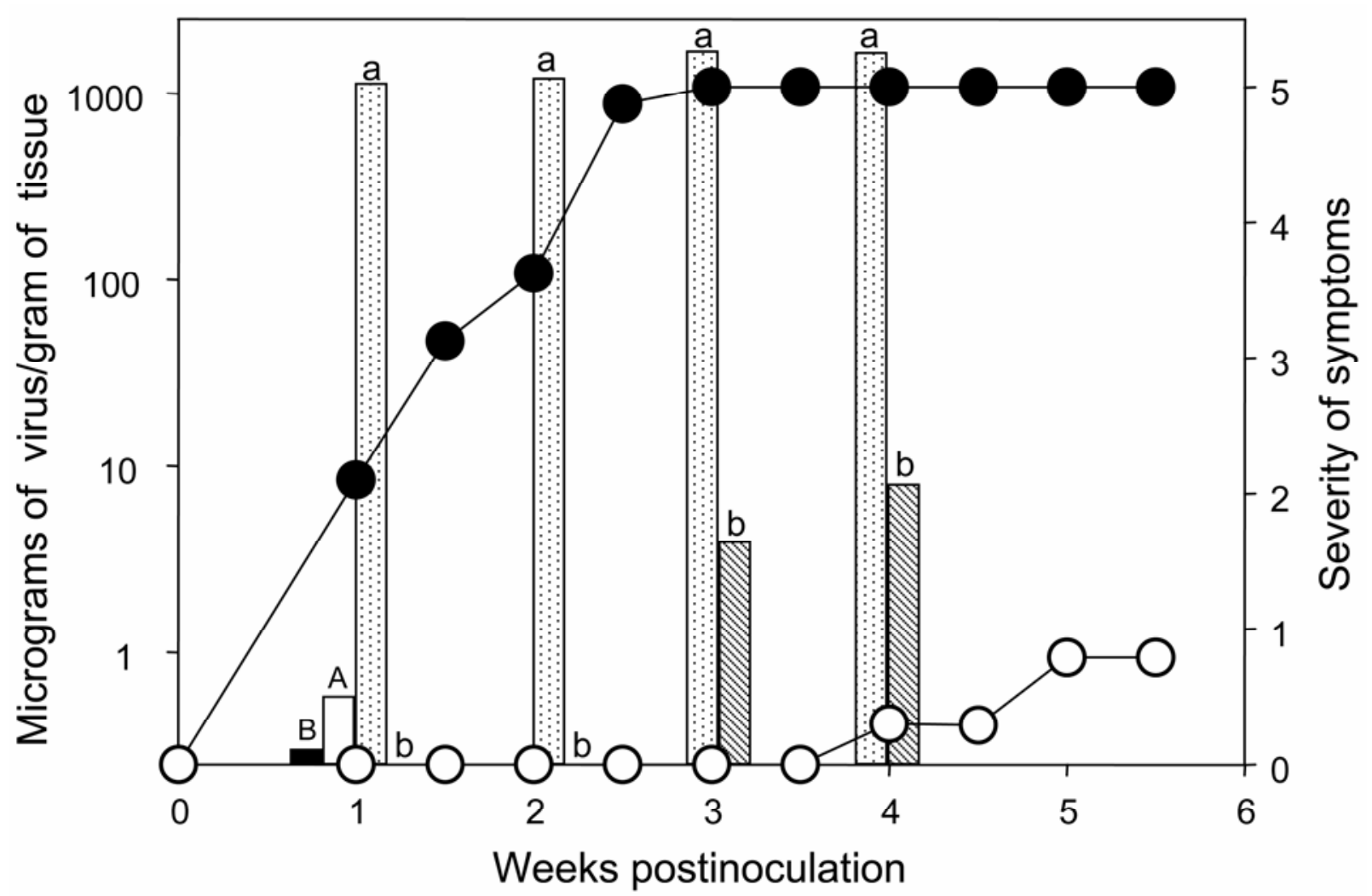

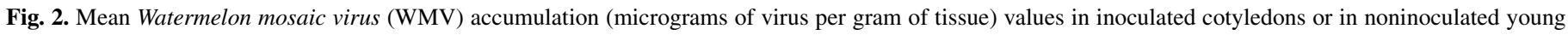

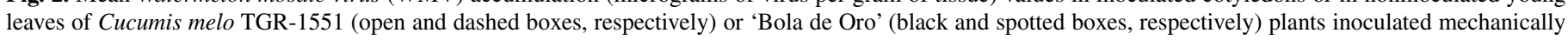

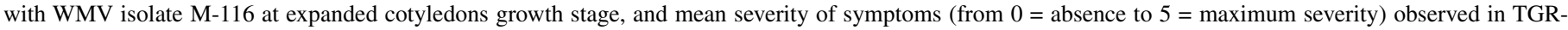

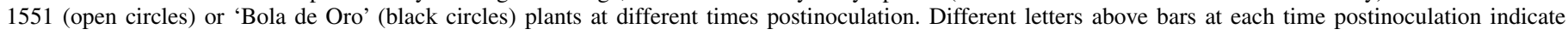
statistically significant differences (uppercase letters for inoculated cotyledons, lowercase letters for noninoculated young leaves). 
plants were susceptible, suggesting a recessive control of resistance. All $\mathrm{BC}_{1 \mathrm{~S}}$ plants were susceptible, and the $\mathrm{F}_{2}$ and $\mathrm{BC}_{1 \mathrm{R}}$ plants showed segregation for resistance. Based on the segregation ratio observed in these two generations, we estimated the number of genes involved in the inheritance of the resistance. For the simplest model studied, one recessive gene (Table 3), the $F_{2}$ segregation did not fit the expected $1 \mathrm{R}: 3 \mathrm{~S}$ ratio, but two more resistant plants would have made the segregation acceptable. The $\mathrm{BC}_{1 \mathrm{R}}$ segregated in an acceptable fit to the ratio $1 \mathrm{R}: 1 \mathrm{~S}$ expected for this model (Table 3). Neither the $\mathrm{F}_{2}$ nor the $\mathrm{BC}_{1 \mathrm{R}}$ data fit the tworecessive-gene model. The observed $\mathrm{F}_{2}$ departure from the expected ratio for the single-gene model could be explained by the existence of an additional dominant gene, epistatic to the recessive resistance gene (Table 3).

\section{DISCUSSION}

TGR-1551 was consistently resistant to WMV when inoculated mechanically or via aphid transmission. The resistance was found to be effective against a collection of WMV isolates from Spain collected in melon production areas. This resistance likely will be useful to control WMV infection throughout the melon-growing

TABLE 2. Efficiency of Myzus persicae and Aphis gossypii in the transmission of Watermelon mosaic virus isolate M116 from infected plants of Cucumis melo TGR-1551 and 'Bola de Oro' to healthy plants of the two same genotypes

\begin{tabular}{llcc}
\hline & & \multicolumn{2}{c}{$\begin{array}{c}\text { Average percentage of plants infected } \\
\text { when using for inoculation }\end{array}$} \\
\cline { 3 - 4 } Transmitter, source & Recipient & 4 aphids/plant & 10 aphids/plant \\
\hline M. persicae & & & \\
Bola de Oro & Bola de Oro & $81.33 \pm 7.22 \mathrm{ab}$ & $98.33 \pm 1.67 \mathrm{a}$ \\
& TGR-1551 & $30.00 \pm 4.94 \mathrm{~cd}$ & $58.33 \pm 11.01 \mathrm{bc}$ \\
TGR-1551 & Bola de Oro & $0.00 \mathrm{e}$ & $8.34 \pm 4.19 \mathrm{de}$ \\
& TGR-1551 & $4.00 \pm 1.63 \mathrm{e}$ & $8.33 \pm 3.19 \mathrm{de}$ \\
A. gossypii & & & \\
Bola de Oro & Bola de Oro & $53.57 \pm 5.84 \mathrm{bc}$ & $81.33 \pm 10.20 \mathrm{ab}$ \\
& TGR-1551 & ND & ND \\
TGR-1551 & Bola de Oro & $0.00 \mathrm{e}$ & $1.33 \pm 1.33 \mathrm{e}$ \\
& TGR-1551 & ND & ND \\
\hline
\end{tabular}

y Transmitter aphid species and virus acquisition source. Virus sources were young leaves of TGR-1551 or 'Bola de Oro' plants systemically infected after mechanical inoculation with M116-WMV (obtained from an aphidinoculated plant) three weeks prior to inoculation of the test materials.

${ }^{\mathrm{z}}$ Six and four replicates were done when using 4 or 10 aphids/plant inoculation pressures, respectively. In every replicate, transmission to 15 healthy plants of each TGR-1551 and Bola de Oro genotype were performed. The number of plants that became infected was determined 30 days after inoculation by visual observation and double-antibody sandwich enzyme-linked immunosorbent assay testing. Mean \pm standard error; mean percentages with the same letter are not significantly different (Games-Howell test procedure, $P \leq 0.05)$; ND $=$ not included because TGR-1551 is resistant to virus transmission by A. gossypii (61). regions of Spain. A recent detailed analysis of the WMV population present in Spain indicated that high biological and genetic homogeneity existed among isolates (42). Also, limited data are available concerning WMV variation elsewhere $(15,42)$. Therefore, usefulness of the resistance found in TGR-1551 for WMV control in other geographical regions needs to be evaluated.

The WMV resistance described here is significant, because few sources of resistance to WMV are available in C. melo (32) and have not been transferred to commercial cultivars despite frequent damage caused by this virus to melon crops worldwide $(12,24$, $36,45,63)$. The most promising resistance to WMV reported to date in $C$. melo was found several years ago in the breeding line 91213, a line derived from PI 371795 (25,43). However, in contrast to TGR-1551, unambiguous WMV symptoms were reported in line 91213. During early infection stages, plants of line 91213 inoculated with WMV exhibited severe mosaic or veinal chlorosis symptoms, which later became less severe as the leaves matured (43). Additionally, in line 91213, mosaic and distortion occasionally appeared in the young leaves of older plants (25). A similar resistant response to WMV was reported for breeding line PI $414723-4 \mathrm{~S}_{3}$ which is closely related to line 91213 and also is derived from PI 371795 (22,41). Inoculated plants of PI 414723$4 \mathrm{~S}_{3}$ initially exhibited severe systemic symptoms in the first one to four leaves above the site of inoculation, but later recovered $(3,22)$. Resistance to WMV in PI $414723-4 S_{3}$ was demonstrated to be controlled by a single dominant gene $(3,22)$, in contrast to the recessive control suggested for the resistance described here. Therefore, the inheritance of resistance to WMV in TGR-1551 differs from inheritance patterns previously reported in C. melo.

A significant reduction in WMV titer and disease symptom expression occurred in TGR-1551 plants (Fig. 2). Thus, TGR1551 is resistant, not immune to infection by WMV $(5,6)$. Virus accumulation and symptoms expression appeared to be under the same or closely linked genetic control.

Genetic analysis indicated that the resistance to WMV found in TGR-1551 was recessive. It is interesting to note that recessive control of resistance is frequent in potyvirus resistance systems $(17,19,20,52)$. We analyzed the possible number of genes involved in the inheritance of the resistance trait. Based on a single gene model, the $\mathrm{BC}_{1 \mathrm{R}}$ segregated in a close fit to the expected $1: 1$, whereas the $F_{2}$ segregated in a close but not acceptable fit to a $1: 3$ resistant:susceptible ratio (Table 3 ). Thus, the single-gene model appears to be valid for use in a backcross breeding scheme to transfer resistance to different horticultural plant and fruit types. However, lack of fit for this single-gene model in $\mathrm{F}_{2}$ segregants suggests that epistatic or genotype-environment effects may influence the expression of resistance. Environmental conditions $(18,51)$, or the susceptible parents employed (14) are known to influence the expression of resistance traits against potyviruses. Further analysis will be needed, therefore, to elucidate the genetic basis of this resistance.

TABLE 3. Goodness of fit $\left(\chi^{2}\right.$ and $P$ ) for genetic models of resistance to Watermelon mosaic virus (WMV) isolate M116 in populations derived from a cross between the resistant TGR-1551 and the susceptible 'Bola de Oro' melons

\begin{tabular}{|c|c|c|c|c|c|c|c|c|c|c|c|c|}
\hline \multirow[b]{2}{*}{ Generation $^{\mathrm{x}}$} & \multicolumn{3}{|c|}{ No. of plants ${ }^{y}$} & \multicolumn{3}{|c|}{ One recessive gene ${ }^{\mathrm{z}}$} & \multicolumn{3}{|c|}{ Two recessive genes ${ }^{\mathrm{z}}$} & \multicolumn{3}{|c|}{ Double recessive $\times$ dominant epitasis } \\
\hline & Total & $\mathrm{R}$ & $\mathrm{S}$ & $\mathrm{R}: \mathrm{S}$ & $\chi^{2}$ & $P$ & $\mathrm{R}: \mathrm{S}$ & $\chi^{2}$ & $P$ & $\mathrm{R}: \mathrm{S}$ & $\chi^{2}$ & $P$ \\
\hline Bola Oro & 22 & 0 & 22 & $0: 1$ & $\ldots$ & $\ldots$ & $0: 1$ & $\ldots$ & $\ldots$ & $0: 1$ & $\ldots$ & $\ldots$ \\
\hline TGR-1551 & 22 & 22 & 0 & 1:0 & $\ldots$ & $\ldots$ & $1: 0$ & $\ldots$ & $\ldots$ & $1: 0$ & $\ldots$ & $\ldots$ \\
\hline $\mathrm{BC}_{1 \mathrm{~S}}$ & 70 & 0 & 70 & $0: 1$ & $\ldots$ & $\ldots$ & $0: 1$ & 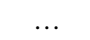 & 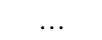 & $0: 1$ & $\ldots$ & $\ldots$ \\
\hline $\mathrm{BC}_{1 \mathrm{R}}$ & 63 & 28 & 35 & $1: 1$ & 0.778 & 0.378 & $1: 3$ & 12.704 & $<0.001$ & $1: 1$ & 0.778 & 0.378 \\
\hline $\mathrm{F}_{2}$ & 131 & 22 & 109 & $1: 3$ & 4.705 & 0.030 & $1: 15$ & 24.855 & $<0.001$ & $3: 13$ & 0.329 & 0.566 \\
\hline
\end{tabular}

${ }^{\mathrm{x}} \mathrm{F}_{1}=\mathrm{TGR}-1551 \times$ Bola Oro, $\mathrm{BC}_{1 \mathrm{~S}}=\mathrm{F}_{1} \times$ Bola Oro, and $\mathrm{BC}_{1 \mathrm{R}}=\mathrm{F}_{1} \times \mathrm{TRG}-1551$.

y Plants (expanded cotyledons growth stage) were inoculated mechanically with WMV M116, and scored for disease symptoms at the end of the fifth week postinoculation, according to an integer scale from 0 (no symptoms) to 5 (severe symptoms). Resistant (R) plants were those with symptom score $\leq 2$; susceptible (S) plants were those with symptom score $>2$.

${ }^{\mathrm{z}} \mathrm{R}: \mathrm{S}=$ expected ratio. 
Recessive resistance genes may interfere with the viral life cycle either at the single-cell level $(44,55)$, during cell-to-cell movement $(4,40)$, or during long-distance transport through the plant $(28,30)$. The mechanism of resistance to WMV of TGR-1551 plants was not associated with early infection stages, because the virus accumulated efficiently in inoculated leaves. Resistant plants supported virus spread into young, noninoculated leaves, although systemic accumulation was greatly reduced. This was observed clearly with the leaf-press blotting analysis of young leaves of WMV-infected plants (Fig. 3). Therefore, some movement-based form of resistance may be operating in TGR-1551. Extensive data are available about the processes associated with virus movement within plants $(23,37,47,48,54,57)$, showing that impaired virus spread is one of the major resistance mechanism of plants to virus infection (23). In fact, many resistance traits have been associated with alteration of virus movement in plants at different levels (cell-to-cell movement or long-distance translocation) $(27,31,56)$. Our data do not distinguish at which stage virus transport may be impaired in TGR-1551 plants, nor can we discern the mechanism responsible for reduced virus titer. Further studies will be needed to more precisely establish the mechanism that is limiting WMV accumulation in TGR-1551 plants.

Restriction of systemic accumulation results in partial resistance and is an efficient means to reduce virus incidence (46). In fact, restricted accumulation of virus in plants may limit availability for vectors, thus reducing subsequent viral spread. It is apparent from our data that the resistance in TGR-1551 significantly limits the ability of WMV to accumulate in infected plants. Localization of WMV within the leaves of TGR-1551-infected plants indicated an uneven distribution with fewer infection foci of smaller size compared with that observed in susceptible plants (Fig. 3). Therefore, reduced amounts of virus are predicted to be available for aphid acquisition in this genotype, which may reduce subsequent virus transmission. This was confirmed during aphid-transmission studies (Table 3). In contrast, with other nonpersistently transmitted viruses (ZYMV and CMV) that readily infect TGR-1551 (16), equivalent transmission rates were obtained for both TGR-1551 and 'Bola de Oro', as demonstrated for M. persicae (data not shown). Therefore, the differences observed between TGR-1551 and 'Bola de Oro' were due to different virus availability and not to resistance of TGR-1551 to the vector $(21,59)$. Accordingly, a significantly lower epidemiological risk of WMV spread is expected for TGR-1551 than for a susceptible melon like 'Bola de Oro' because (i) TGR-1551 plants showed a lower propensity to be infected by WMV and (ii) TGR-1551 plants infected with WMV were less efficient virus sources for secondary spread. Therefore, our results suggest that TGR-1551 could be a valuable resistance source to reduce production losses caused by WMV.

Interestingly, TGR-1551 plants also exhibit resistance to the vector A. gossypii (21), similar to plants of the breeding line 91213 (26). Moreover, virus inoculation by A. gossypii is impeded in this genotype (61), similar to previous observations for C. melo accession PI 161375 (50). In addition, TGR-1551 plants are resistant to Cucurbit yellowing stunting disorder virus (genus Crinivirus, family Closteroviridae) $(34,39)$, and to the biotype $\mathrm{B}$ of its natural vector, the sweet-potato whitefly Bemisia tabaci (Hemiptera: Aleyrodidae) (60). The results obtained here emphasize the potential importance of the line TGR-1551 as a donor of multiple disease and pest resistance for melon breeding programs.

\section{ACKNOWLEDGMENTS}

This research was supported by grant 1FD97-0271 (Comisión Interministerial de Ciencia y Tecnología, CICYT, Spain, and European Union). J. A. Díaz-Pendón is the recipient of a fellowship from Ministerio de Educación, Cultura y Deporte, Spain. We thank M. V. Martín and
R. Camero for their technical assistance, A. Fereres for providing $M$. persicae and A. gossypii individuals, and J. McCreight for his constructive discussion of the article and help to produce an improved English version.

\section{LITERATURE CITED}

1. Alonso-Prados J. L., Fraile, A., and García-Arenal, F. 1997. Impact of Cucumber mosaic virus and Watermelon mosaic virus 2 infection on melon production in central Spain. J. Plant Pathol. 79:131-134.

2. Alonso-Prados, J. L., Luis-Arteaga, M., Alvarez, J. M., Moriones, E., Batlle, A., Laviña, A., García-Arenal, F., and Fraile, A. 2003. Epidemics of aphid-transmitted viruses in melon crops in Spain. Eur. J. Plant Pathol. 109:129-138.

3. Anagnostou, K., Jahn, M., and Perl-Treves, R. 2000. Inheritance and linkage analysis of resistance to Zucchini yellow mosaic virus, Watermelon mosaic virus, Papaya ringspot virus and powdery mildew in melon. Euphytica 116:265-270.

4. Arroyo, R., Soto, M. J., Martínez-Zapater, J. M., and Ponz, F. 1996. Impaired cell-to-cell movement of potato virus $\mathrm{Y}$ in pepper plants carrying the $\mathrm{y}(\mathrm{a})(\mathrm{pr} 2(1))$ resistance gene. Mol. Plant-Microbe Interact. 9:314-318

5. Birch, R. G. 2001. Disease resistance. Pages 356-364 in: Encyclopedia of Plant Pathology. O. C. Maloy and T. D. Murray, eds. John Wiley \& Sons, Inc., New York.

6. Birch, R. G. 2001. Tolerance. Page 1029 in: Encyclopedia of Plant Pathology. O. C. Maloy and T. D. Murray, eds. John Wiley \& Sons, Inc., New York.

7. Blua, M. J., and Perring, T. M. 1989. Effect of Zucchini yellow mosaic virus on development and yield of cantaloupe (Cucumis melo). Plant Dis. 73:317-320.

8. Campbell, C. L., and Madden, L. V. 1990. Introduction to Plant Disease Epidemiology. John Wiley \& Sons, Inc., New York.

9. Caranta, C., Pflieger, S., Lefebvre, V., Daubeze, A. M., Thabuis, A., and Palloix, A. 2002. QTLs involved in the restriction of cucumber mosaic virus (CMV) long-distance movement in pepper. Theor. Appl. Genetics 104:586-591.

10. Castle, S. J., Perring, T. M., Farrar, C. A., and Kishaba, A. N. 1992. Field and laboratory transmission of Watermelon mosaic virus 2 and Zucchini yellow mosaic virus by various aphid species. Phytopathology 82:235240.

11. Clark, M. F., and Adams, A. N. 1977. Characteristics of the microplate method of enzyme-linked immunosorbent assay for detection of plant viruses. J. Gen. Virol. 34:475-483.

12. Cohen, S., and Nitzany, F. E. 1963. Identity of viruses affecting cucurbits in Israel. Phytopathology 53:193-196.

13. Coudriet, D. L. 1962. Efficiency of various insects as vectors of Cucumber mosaic and Watermelon mosaic viruses in cantaloupes. J. Econ. Entomol. 55:519-520.

14. Danin-Poleg, Y., Paris, H. S., Cohen, S., Rabinowitch, H. D., and Karchi, Z. 1997. Oligogenic inheritance of resistance to zucchini yellow mosaic virus in melons. Euphytica 93:331-337.

15. Desbiez, C., and Lecoq, H. 2004. The nucleotide sequence of Watermelon mosaic virus (WMV, Potyvirus) reveals interspecific recombination between two related potyviruses in the 5' part of the genome. Arch. Virol. 149:1619-1632.

16. Díaz, J. A., Mallor, C., Soria, C., Camero, R., Garzo, E., Fereres, A., Alvarez, J. M., Gómez-Guillamón, M. L., Luis-Arteaga, M., and Moriones, E. 2003. Potential sources of resistance for melon to nonpersistently aphid-borne viruses. Plant Dis. 87:960-964.

17. Díaz-Pendón. J. A., Truniger, V., Nieto, C., García-Mas, J., Bendhamane, A., and Aranda, M. A. 2004. Advances in understanding recessive resistance to plant viruses. Mol. Plant Pathol. 5:223-233.

18. Fisher, M. L., and Kyle, M. M. 1996. Inheritance of resistance to potyviruses in Phaseolus vulgaris L. 4. Inheritance, linkage relations, and environmental effects on systemic resistance to four potyviruses. Theor. Appl. Genetics 92:204-212.

19. Fraser, R. S. S. 1990. The genetics of resistance to plant viruses. Annu. Rev. Phytopathol. 28:179-200.

20. Fraser, R. S. S. 1992. The genetics of plant-virus interactions-Implications for plant-breeding. Euphytica 63:175-185.

21. Garzo, E., Soria, C., Gómez-Guillamón, M. L., and Fereres, A. 2002. Feeding behavior of Aphis gossypii on resistant accessions of different melon genotypes (Cucumis melo). Phytoparasitica 30:129-140.

22. Gilbert, R. Z., Kyle, M. M., Munger, H. M., and Gray, S. M. 1994. Inheritance of resistance to Watermelon mosaic virus in Cucumis melo L. Hortscience 29:107-110.

23. Gilbertson, R. L., and Lucas, W. J. 1996. How do viruses traffic on the 'vascular highway'? Trends Plant Sci. 1:260-268. 
24. Grafton-Cardwell, E. E., Perring, T. M., Smith, R. F., Valencia, J., and Farrar, C. A. 1996. Occurrence of mosaic viruses in melons in the Central Valley of California. Plant Dis. 80:1092-1097.

25. Gray, S. M., Moyer, J. W., and Kennedy, G. G. 1988. Resistance in Cucumis melo to Watermelon mosaic virus-2 correlated with reduced virus movement within leaves. Phytopathology 78:1043-1047.

26. Gray, S. M., Moyer, J. W., Kennedy, G. G., and Campbell, C. L. 1986. Virus suppression and aphid resistance effects on spatial and temporal spread of Watermelon mosaic virus-2. Phytopathology 76:1254-1259.

27. Guerini, M. N., and Murphy, J. F. 1999. Resistance of Capsicum annuum 'Avelar' to pepper mottle potyvirus and alleviation of this resistance by co-infection with Cucumber mosaic cucumovirus are associated with virus movement. J. Gen. Virol. 80:2785-2792.

28. Hamalainen, J. A., Kekerainen, T., Gebhardt, C., Watanabe, K. N., and Valkonen, J. P. 2000. Recessive and dominant genes interfere with the vascular transport of Potato virus A in diploid potatoes. Mol. PlantMicrobe Interact. 13:402-412.

29. Hawkes, R., Niday, E., and Gordon, J. 1982. A dot-immunobinding assay for monoclonal and other antibodies. Ann. Biochem. 119:142-147.

30. Kabelka, E., Ullah, Z., and Grumet, R. 1997. Multiple alleles for Zucchini yellow mosaic virus resistance at the zym locus in cucumber. Theor. Appl. Gen. 95:997-1004.

31. Kobori, T. Ohki, S. T., and Osaki, T. 2000. Movement of Cucumber mosaic virus is restricted at the interface between mesophyll and phloem pathway in Cucumis figarei. J. Gen. Plant Pathol. 68:81-88.

32. Lecoq, H., Wisler, G. C., and Pitrat, M. 1998. Cucurbit viruses: The classics and emerging. Pages 126-142 in: Cucurbitaceae '98, Evaluation and Enhancement of Cucurbit Germplasm. J. D. McCreight, ed. ASHS, Alexandria, VA.

33. López-Abella, D., Bradley, R. H. E., and Harris, K. F. 1988. Correlation between stylet paths made during superficial probing and the ability of aphids to transmit nonpersistent viruses. Pages 251-258 in: Advances in Disease Vector Research. K. F. Harris, ed. Springer-Verlag, New York.

34. Lopez-Sesé, A. I., and Gómez-Guillamón, M. L. 2000. Resistance to Cucurbit yellowing stunting disorder virus (CYSDV) in Cucumis melo L. Hortscience 35:110-113.

35. Lovisolo, O. 1980. Virus and viroid diseases of cucurbits. Acta Hortic. 88:33-88.

36. Lovisolo, O., and Lisa, V. 1983. Virosi e micoplasmosi delle Cucurbitaceae. Ital. Agric. 120:58-72.

37. Lucas, W. J., and Gilbertson, R. L. 1994. Plasmodesmata in relation to viral movement within leaf tissue. Annu. Rev. Phytopathol. 32:387-411.

38. Luis-Arteaga, M., Alvarez, J. M., Alonso-Prados, J. L., Bernal, J. J., García-Arenal, F., Laviña, A., Batlle, A., and Moriones, E. 1998. Occurrence, distribution, and relative incidence of mosaic viruses infecting field-grown melon in Spain. Plant Dis. 82:979-982.

39. Marco, C. F., Aguilar, J. M., Abad, J., Gomez-Guillamón, M. L., and Aranda, M. A. 2003. Melon resistance to Cucurbit yellow stunting disorder virus is characterized by reduced virus accumulation. Phytopathology 93:844-852.

40. Masuta, C., Nishimura, M., Morishita, H., and Hataya, T. 1999. A single amino acid change in viral genome-associated protein of potato virus $\mathrm{Y}$ correlates with resistance breaking in 'Virgin A Mutant' tobacco. Phytopathology 89:118-123.

41. McCreight, J. D., Bohn, G. W., and Kishaba, A. N. 1992. 'Pedigree' P.I. 414723 melon. Cucurbit Genet. Coop. Rep. 15:51-52.

42. Moreno, I. M., Malpica, J. M., Díaz-Pendón, J. A., Moriones, E., Fraile, A., and García-Arenal, F. 2003. Variability and genetic structure of the population of Watermelon mosaic virus infecting melon in Spain. Virology 318:451-460.
43. Moyer, J. W., Kennedy, G. G., and Romanow, L. R. 1985. Resistance to Watermelon mosaic virus-II multiplication in Cucumis melo. Phytopathology 75:201-205.

44. Murphy, J. F., Blauth, J. R., Livingstone, K. D., Lackney, V. K., and Jahn, M. K. 1998. Genetic mapping of the pvr1 locus in Capsicum spp., and evidence that distinct potyvirus resistance loci control responses that differ at the whole plant and cellular levels. Mol. Plant-Microbe Interact. 11:943-951.

45. Nameth, S. T., Dodds, J. A., Paulus, A. O., and Laemmlen, F. F. 1986. Cucurbit viruses of California: An ever-changing problem. Plant Dis. 70:8-12.

46. Nono-Wondim, R. Gebre-Selassie, K., Palloix, A., Pochard, E., and Marchoux, G. 1993. Study of multiplication of Cucumber mosaic virus in susceptible and resistant Capsicum anпиum lines. Ann. Appl. Biol. 122:49-56.

47. Oparka, K. J., Roberts, A. G., Boevink, P., Santa Cruz, S., Roberts, L., Pradel, K. S., Imlau, A., Kotlizky, G., Sauer, N., and Epel, B. 1999. Simple, but not branched, plasmodesmata allow the nonspecific trafficking of proteins in developing tobacco leaves. Cell 97:743-754.

48. Pennazio, S., Roggero, P., and Conti, M. 1999. Plasmodesmata and plant viruses. A centenary story. Microbiologica 22:389-404.

49. Perring, T. M., Gruenhagen, N. M., and Farrar, C. A. 1999. Management of plant viral diseases through chemical control of insect vectors. Annu. Rev. Entomol. 44:457-481.

50. Pitrat, M., and Lecoq, H. 1980. Inheritance of resistance to cucumber mosaic virus transmission by Aphis gossypii in Cucumis melo. Phytopathology 70:958-961.

51. Pitrat, M., and Lecoq, H. 1984. Inheritance of Zucchini yellow mosaic virus resistance in Cucumis melo. Euphytica 33:57-61.

52. Provvidenti, R., and Hampton, R. O. 1992. Sources of resistance to viruses in the Potyviridae. Arch. Virol. 5:189-211.

53. Raccah, B. 1986. Nonpersistent viruses-Epidemiology and control. Adv. Virus Res. 31:387-429.

54. Santa Cruz, S. 1999. Perspective: Phloem transport of viruses and macromolecules-What goes in must come out. Trends Mircrobiol. 7:237-241.

55. Sato, M., Masuta, C., and Uyeda, I. 2003. Natural resistance to Clover yellow vein virus in beans controlled by a single recessive locus. Mol. Plant-Microbe Interact. 16:994-1002.

56. Schaad, M. C., and Carrington, J. C. 1996. Suppression of long-distance movement of Tobacco etch virus in a nonsusceptible host. J. Virol. 70:2556-2561

57. Seron, K., and Haenni, A. L. 1996. Vascular movement of plant viruses. Mol. Plant-Microbe Interact. 9:435-442.

58. Sevik, M. A., and Arli-Sokmen, M. 2003. Viruses infecting cucurbits in Samsun, Turkey. Plant Dis. 87:341-344.

59. Soria, C., Díaz, J. A., Moriones, E., and Gómez-Guillamón, M. L. 2000. Resistance to Aphis gossypii and to virus transmission by this aphid in melon. Proc. Eucarpia Cucurbit Genet. Breed. 2000. M. Katzir and H. S. Paris, eds. Acta Hortic. (ISHS 2000) 510:305-312.

60. Soria, C., López-Sesé, A. I., and Gómez-Guillamón, M. L., 1999. Resistance of Cucumis melo L. against Bemisia tabaci Gennadius. Environ. Entomol. 28:831-835.

61. Soria, C., Moriones, E., Fereres, A., Garzo, E., and Gómez-Guillamón, M. L. 2003. New source of resistance to virus transmission by Aphis gossypii in melon. Euphytica 133:313-318

62. Ullah, Z., and Grumet, R. 2002. Localization of Zucchini yellow mosaic virus to the veinal regions and role of viral coat protein in veinal chlorosis conditioned by the zym potyvirus resistance locus in cucumber. Physiol. Mol. Plant Pathol. 60:79-89.

63. Ullman, D. E., Cho, J. J., and German, T. L. 1991. Occurrence and distribution of cucurbit viruses in the Hawaiian Islands. Plant Dis. 75:367-370. 